\title{
Dental Evidence in Forensic Identification - An Overview, Methodology and Present Status
}

\author{
Kewal Krishan ${ }^{1, *}$, Tanuj Kanchan ${ }^{2}$ and Arun K. Garg ${ }^{3}$ \\ ${ }^{I}$ Department of Anthropology, Panjab University, Chandigarh, India; ${ }^{2}$ Department of Forensic Medicine, Kasturba \\ Medical College, Mangalore (A Constituent Institute of Manipal University), India; ${ }^{3}$ Department of Orthodontics, \\ Dr. Harvansh Singh Judge Institute of Dental Sciences and Hospital, Panjab University, Chandigarh, India
}

\begin{abstract}
Forensic odontology is primarily concerned with the use of teeth and oral structures for identification in a legal context. Various forensic odontology techniques help in the identification of the human remains in incidents such as terrorists' attacks, airplane, train and road accidents, fires, mass murders, and natural disasters such as tsunamis, earth quakes and floods, etc. (Disaster Victim Identification-DVI). Dental structures are the hardest and well protected structures in the body. These structures resist decomposition and high temperatures and are among the last ones to disintegrate after death. The principal basis of the dental identification lies in the fact that no two oral cavities are alike and the teeth are unique to an individual. The dental evidence of the deceased recovered from the scene of crime/occurrence is compared with the ante-mortem records for identification. Dental features such as tooth morphology, variations in shape and size, restorations, pathologies, missing tooth, wear patterns, crowding of the teeth, colour and position of the tooth, rotations and other peculiar dental anomalies give every individual a unique identity. In absence of ante-mortem dental records for comparison, the teeth can help in the determination of age, sex, race/ethnicity, habits, occupations, etc. which can give further clues regarding the identity of the individuals. This piece of writing gives an overview of dental evidence, its use in forensic identification and its limitations.
\end{abstract}

Keywords: Age estimation, bite marks, dental anomalies, forensic odontology, sex and race determination from teeth, wrongful convictions.

\section{INTRODUCTION}

"Forensic odontology is a branch of dentistry which deals with the proper handling and examination of dental evidence and the proper evaluation and presentation of dental findings in the interest of justice" [1]. In the present scenario, forensic odontology has been included as a specialty in the broad arena of Forensic Sciences. Forensic odontology has become an integral part of large international forensic educational organizations like American Academy of Forensic Sciences (AAFS) as well as International Association of Identification (IAI). The primary utility of forensic odontology is in identification of human remains based upon the individualistic characteristics present in the teeth of different individuals. This discipline plays a significant role in the identification of human remains in incidents such as tsunamis, earth quakes, land slides, bomb blasts and terrorist attacks, air plane crashes, train and road accidents, etc. where highly mutilated and dismembered dead bodies are recovered which are beyond recognition $[2,3]$. This process of identification of the disaster victims is known as Disaster Victim Identification (DVI). Teeth are the strongest part of the human body, which can withstand high explosion and are not damaged by such incidents $[4,5]$. Thus, teeth are likely to be recovered in mass

*Address correspondence to this author at the Department of Anthropology, Panjab University, Sector-14, Chandigarh, India; Tel: +91-9876048205;

E-mails: gargkk@yahoo.com; kewalkrishan@pu.ac.in fatality incidents where the other means of identification such as fingerprints and facial features are destroyed.

Adult human dentition comprises of incisors, canines, premolars and molars that vary in shape, size, and interspaces between the teeth among different individuals. The way these teeth are arranged in different oral cavities are unique in every individual [6]. At the same time, every tooth possesses a set of unique characteristics called 'tooth class characteristics' which form the basis of identification. The other features which help in identification are dental pathology, restorations, dental anomalies, etc. [7]. Besides, age, sex, race/ ethnicity, occupation, and habits etc. can be determined from teeth [8]. The present review is an attempt to highlight on the importance of teeth in the identification process, its utility in the estimation of biological profile (age, sex, race etc.) and the present status of dental evidence in forensics. The review also focuses on the amount of information that can be extracted about the victim from the teeth using dental anomalies and other dental records.

\section{AGE DETERMINATION}

Dental maturity plays an important role in the estimation of age in children and adolescents [9]. The number and sequence of the teeth erupted can fairly determine the age of an individual. Radiographic methods can further elaborate about the various stages of mineralization $[10,11]$ and further help in a more accurate estimation of age. The teeth 
mineralization give a better estimate of chronological age than the bone mineralization [12] since mineralization stages in the teeth are less affected by variation in nutritional and endocrine status of the individual. In this regard, the developmental stages of the teeth as given by Demirjian et al. [13] are much in use for estimation of chronological age throughout the world. For estimation of age in adults, Gustafson developed a method of age estimation from a single tooth way back in 1950 [14]. The technique utilizes various stages of regressive changes in the teeth such as occlusal attrition, coronal secondary dentine formation, the loss of periodontal attachment, cementum apposition, amount of apical resorption and the transparency of the root [12]. Johnson [15] made improvements in the technique described by Gustafson which is now mostly used by forensic scientists for estimation of age in adults. Kvaal et al. [16] developed another method of age estimation in adults by measuring the size of the pulp from periapical radiographs of the teeth dependent upon the sex of the individual.

While determining the age of a victim/ accused who is yet to attain adulthood; the simplest way is to examine the eruption status of teeth in the oral cavity. This gives an idea to the observer about the number of teeth erupted. A rough idea of the age can be taken from the sequence and the numbers of teeth erupted in case of children and adolescents. These records and observations can be used in collaboration with other methods of age estimation for more accurate results depending upon the material available for examination.

\section{SEX DETERMINATION}

Although sex determination from teeth is not conclusive, in the absence of other evidence, teeth can give a clue regarding the sex of the individual. The results can be further correlated and substantiated with other facts and data available to the forensic scientist. Odontometrics, a technique to take measurements on the teeth has been used by the scientists for sex determination $[17,18]$. The sex determination using this technique is based on the sexual dimorphism of the size of the teeth. Mesio-distal and bucco-lingual tooth dimensions have been used for sex determination in the past $[19,20]$. These measurements are termed as linear measurements. However, diagonal measurements are helpful in measuring rotated, crowded and proximally restored teeth [21]. Certain dental indices such as Incisor Index, Mandibular-Canine Index, Crown Index etc. have been derived from linear measurements of the teeth to show sexual dimorphism in the teeth [22-24]. The mandibular canines are shown to exhibit greater sexual dimorphism than the maxillary canines. According to Joseph et al. [21], the overall accuracy rate of odontometric sex determination is $\sim 72 \%$. Besides, a non-metric feature on both upper and lower canines; 'canine distal accessory ridge' located on the lingual surface between the medial lingual ridge and distal marginal ridge has been found to show sexual dimorphism [25]. This ridge is more pronounced and more frequency found in males than females.

A more recent method of sex determination from teeth is the presence of sex chromatin or Barr bodies in the pulp of the teeth [26, 27], according to the method devised by Barr $\&$ Bertram [28]. The studies have also been carried out to extract DNA from the pulp tissue as well as dentine [29, 30] and its use for sex determination using Polymerase Chain Reaction (PCR). Enamel protein [31] due to its different patterns in males and females has also been used for sex determination using DNA techniques. Amelogenin or AMEL is a major protein found in the enamel of humans. Amelogenin has different patterns of nucleotide sequence in the enamels of males and females. Amelogenin gene for the very first time was sequenced by Nakahori et al. [32, 33]. Two different AMEL genes, one located on chromosome $\mathrm{X}$ and one on the $\mathrm{Y}$ chromosome are found in males, however, females have two identical AMEL genes located on X chromosome [34]. According to Michael and Brauner [35], the amelogenin test for determination of sex, should be interpreted cautiously.

\section{RACE DETERMINATION, OCCUPATION/HABITS AND CULTURAL PRACTICES}

Certain morphological features of the teeth are known to show population variation which can be used to distinguish the ethnicity or ancestry. However, the determination of race from morphological features of the teeth remains debatable. These features, characteristics and occupational marks give an idea about the habits and cultural practices of a group of people/ethnicity. The dental characteristics such as the shovelling or scooping of the upper incisor (most common in Asiatic Mongoloids and Amerindians), taurodontism, chisel shaped incisors, Carabelli's cusp, hypocone, and protostylid, peg shaping of the teeth can be used to determine the ethnicity of the individual [36-38]. According to Vij [8], Aborigines Australians, the Melanesians and the American Indians and Eskimos tend to be large toothed races with wide crowns and Lapps and Bushmen are small people with comparatively smaller teeth.

Dental restorations sometimes may indicate the ethnicity of the individual [39], methods of restorations in certain countries or regions may be unique and may not be used at any other place. The use of expensive restorations may also suggest social and economic status of an individual [40].

It has also been observed that teeth can provide important evidence regarding the habits and occupations of the individuals. Dressmakers or tailors keep needles between their teeth, thread biting in sewing; cobblers, carpenters and electricians hold nails between their incisors; pencil and pen biting, opening tops of bottles with the teeth [41]. Certain habits like pipe smoking, cigarette smoking and tobacco chewing can also leave their mark on the teeth. Excessive tooth wear has been observed in mining industry associated with the exposure to olivine dust in the work environment [42]. Artificial deformations sometimes lead to identification of the person as they may be related with the cultural practices of a particular group of population. Most often the central incisors are involved in the artificial deformation as they are most visible from outside the mouth.

\section{COMPARISON OF DENTAL RECORDS AND ANOMALIES IN THE TEETH}

Forensic odontologists are involved in assisting the law enforcing agencies in proper presentation of the dental evi- 
dence collected from the scene of crime or mass fatality incidents. The dental evidence is compared with the antemortem records available to the dentists for identification of the deceased [43] in DVI. These comparisons can be achieved by using dental radiographs $[11,44]$ and dental records available with the dentists. Sometimes, the dental evidence can be compared with the ante-mortem photographs available with the family members usually showing the anterior teeth [7]. The dental records are based upon the universal dental numbering system and contain a plenty of information about the teeth of the individual. The forensic dental comparison involves the comparison of certain important features of the teeth which can be termed as individualizing characteristics such as dental fillings, extractions, surface structure/root configuration, adjacent teeth, crowding of particular teeth, diastema, dental spacing (Fig. 1), twisted/ tilted teeth, teeth rotations and transpositions, missing teeth, extra teeth, supernumerary cusps on the occlusal aspect of the teeth (Fig. 2), other teeth anomalies and developmental disturbances etc.

Variation in tooth morphology has been an enduring interest to a dental anthropologist and a forensic odontologist as they help in classification of population groups and identification of the individual forensic examinations respectively Hanihara [45]. Dental anomalies and variations include disturbances in tooth size such as microdontia (smaller teeth than normal) and macrodontia (larger teeth than normal); disturbances in the number of teeth such as anodontia (congenital absence of teeth), polydontia or hyperdontia (having extra teeth); disturbances in eruption of teeth such as impacted teeth (failed to erupt and remain buried in the alveolar bone) and ectopic eruption (when a tooth cannot complete its eruption because it is blocked by an adjacent tooth or by a misplaced orthodontic band--usually on a first molar tooth); disturbances in shape of the tooth such as dilaceration and flexion (is a severe bend in the long axis of the tooth), tauro- dontism (bull like teeth having abnormally long pulp chamber and short roots), supernumerary cusps such as Carabelli's cusp, talon cusp, peg shaped lateral incisors (Fig. 3), and variations in the number of roots of the teeth, shovel shaped incisors; disturbances in eruption of the teeth such as enamel pearls (small nodules of enamel found on the root of the tooth close to or at the cemento-enamel junction), Hutchinson's incisors or mulberry molars (sometimes are called screwdriver teeth), winged incisors (a special case of rotation of the upper central incisors) and enamel hypoplasia [46] (severe sickness or nutritional deprivation) and enamel imperfecta (amelogenesis imperfecta) (Fig. 4). Sometimes, the type of occlusion between the mandibular and maxillary teeth also helps in identifying the person; the occlusion may be of three types: overbite or deep over bite (Fig. 5), normal bite and underbite [47]. All these anomalies and dental variations help in the comparison of ante-mortem and postmortem match and confirm the identity of an individual. The dental characteristics and anomalies help in establishing the uniqueness and identity of the deceased in forensic examinations. The dental characteristics can potentially lead to a positive identification in the same manner as in case of DNA profiling and morphological fingerprints. These characteristics however, may not be of much help to the investigator in absence of ante-mortem dental records, or where comparison of the post-mortem dental records is not possible. Still from the dental records available, at least, the investigator may narrow down the information by estimating the biological profile (estimation of age, sex, race etc.) of the deceased.

\section{BITE MARKS}

The teeth are unique to an individual; even a single tooth of a person is highly individualist to a person. Bite marks inflicted by the teeth are similarly considered to be highly individualistic to a person and are hence of considerable
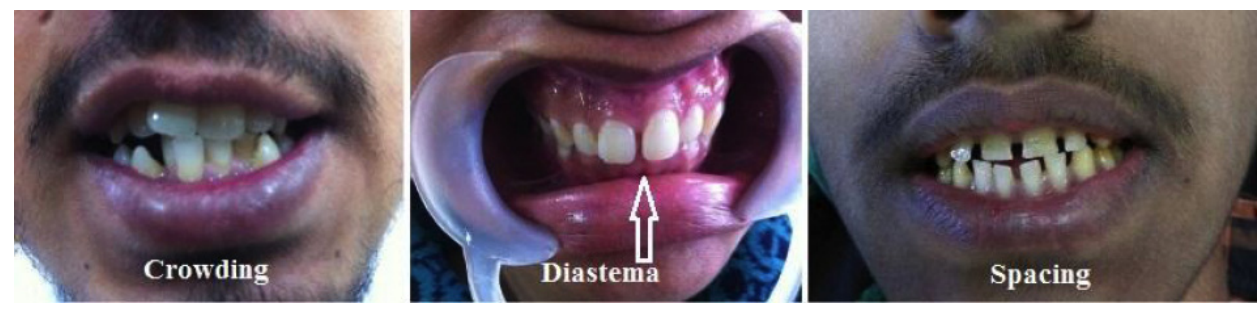

Fig. (1). Photographs showing crowding, diastema and spacing in the teeth.
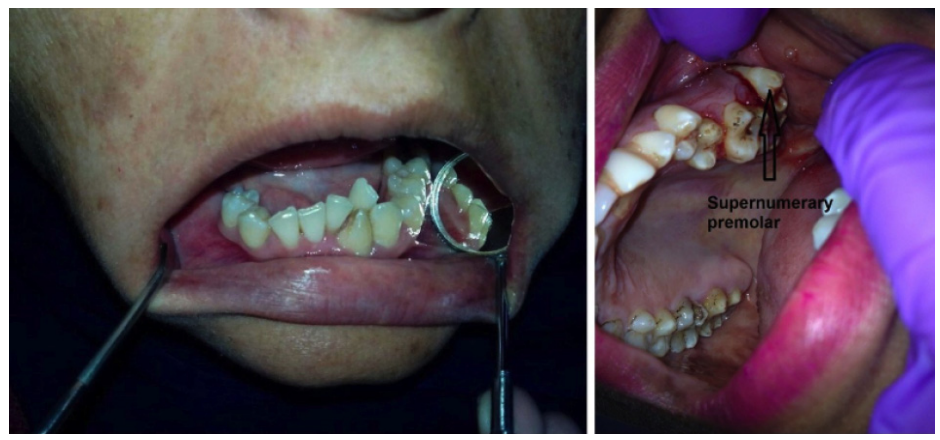

Fig. (2). Photographs showing transposition of canine with lateral incisors and supernumerary premolar. 

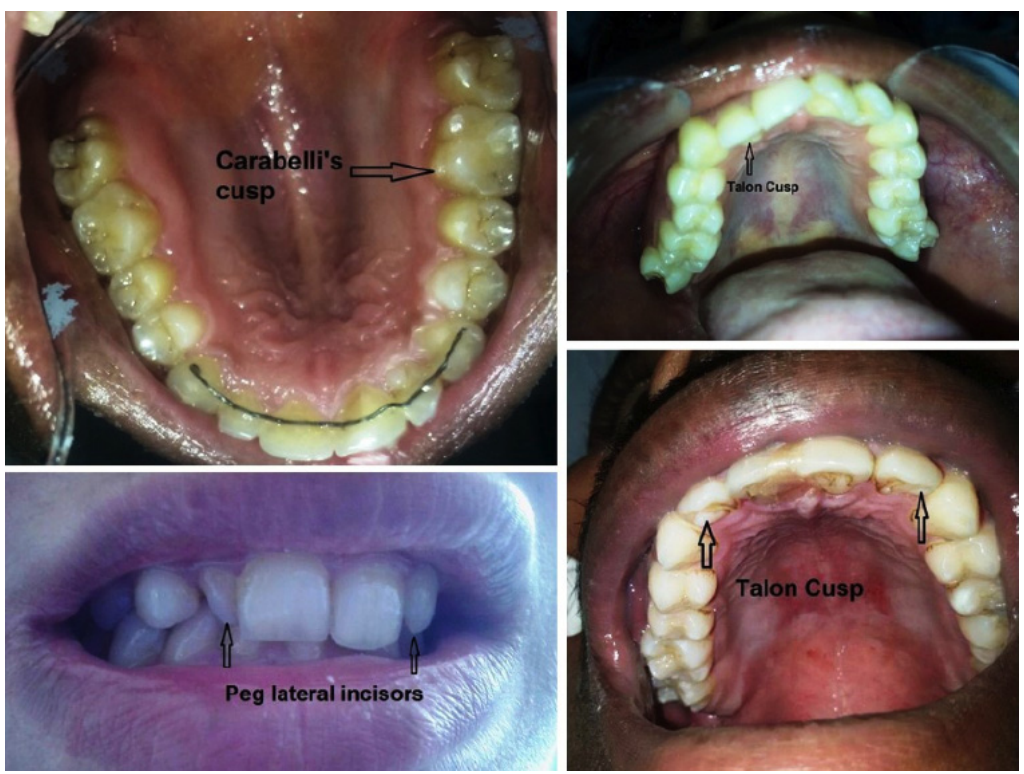

Fig. (3). Photographs showing Carabelli's cusp, Talon's cusps and Peg lateral incisors.
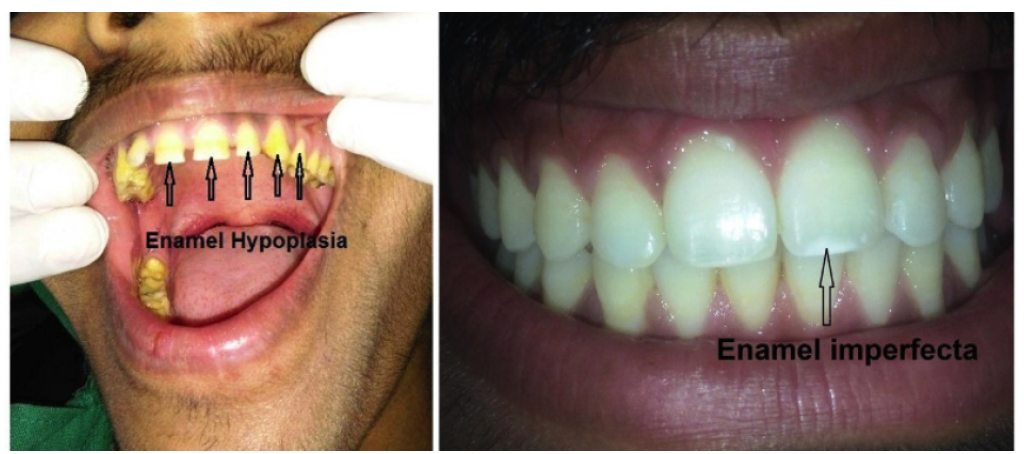

Fig. (4). Photographs showing enamel hypoplasia and enamel imperfecta (Amelogenesis imperfecta).

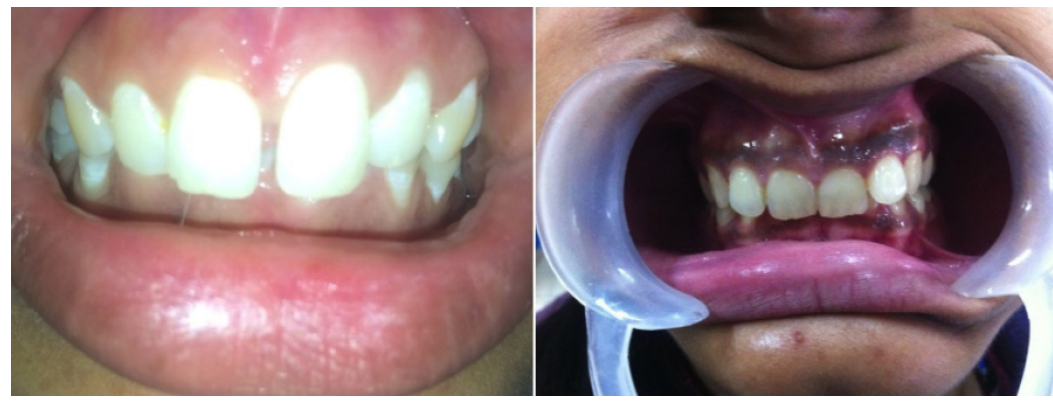

Fig. (5). Photographs showing deep bite or deep over bite where the maxillary teeth almost completely overlap the mandibular teeth.

importance from forensic point of view [48, 49]. This aspect of forensic odontology has received substantial attention in scientific writings and media to its controversial aspect [50]. There are many cases in which the bite mark evidence has been considered important and has led to the conviction of the culprits. Bite marks may be present on the body of the victim on sites such as cheeks, buttocks, legs, lips, or any other part of the body or can be seen on the arm or face of the attacker against whom the victim has tried to defend. The bite marks can also be found on the eatables like hard cheese, butter, fruits etc. The cast of the bite marks can be made or photographs of the surface can be taken and compared with the original or the cast of the teeth [51]. Missing teeth, malformed teeth, fractures, crowding of the teeth, diastema and other peculiar characteristics of the teeth are helpful in the comparison process on these individualistic characters.

\section{PALATAL RUGAE}

Palatal rugae (Plica palatine) are the irregular and asymmetric anatomical folds that are located on the anterior third of the palate behind the incisive papillae (Fig. 6). They are considered to be unique to an individual and their morphology remains stable throughout life however; they change in size due to the growth and development of the palate. This 

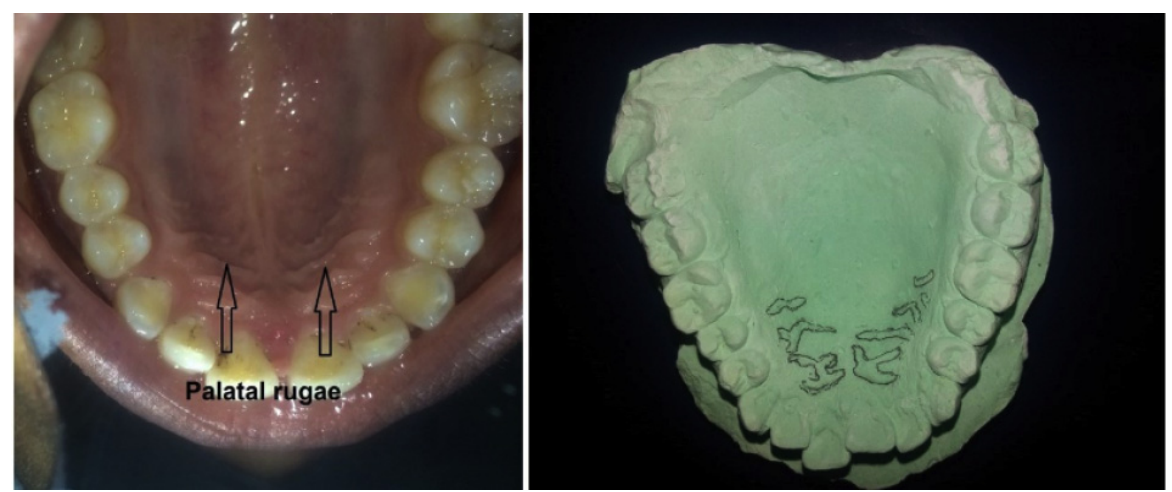

Fig. (6). Photographs showing palatal rugae in mouth and a dental cast.

feature makes them a good identification parameter in forensic examination. They are particularly important in the identification of edentulous persons. They can also be studied in burnt and decomposed bodies where the other possible means of identification are destroyed. They may be affected by trauma, extreme finger sucking in infancy, and persistent pressure with orthodontic treatment and dentures $[52,53]$. If they are destroyed, in some cases, they may recuperate their form afterwards in the living beings. Various past studies confirm their uniqueness, individualization $[54,55]$ and their probable use in estimation of sex [56] in forensic examinations.

\section{QUESTIONABLE DENTAL EVIDENCE AND WRONGFUL CONVICTIONS}

Although dental records can serve as proof and hard evidence for DVI and many of the other medico-legal cases where other evidence is not available for forensic comparison, however, the bite mark evidence is questionable. This evidence may be based upon the flawed indicative reasoning and absence of true scientific and statistical validation [57]. Although, new methods have been developed by forensic odontologists all over the world for identification and comparison of the bite mark evidence, however, it lacks in control on process, procedure, methodology and competence. According to The Innocence Project in New York [58], there are many documented cases in the literature where people were wrongfully convicted on the basis of bite mark evidence and sent to prison. They were exonerated when DNA taken from the same bite marks proved that the bite marks do not belong to them. According to a recent article appeared in British journal 'Nature' [59], there is a little evidence that bite marks on a crime victim's skin allow reliable identification of the perpetrator. The 'Nature' article primarily focuses on wrongful convictions in forensic sciences with the unreliable methods such as bite mark analysis. Due to such wrongful convictions in forensic sciences, The US Department of Justice and the National Institute of Standards and Technology, U.S.A. established the first US National Commission on Forensic Science in the month of February 2014, where 37 scientists, lawyers, forensic practitioners and lawenforcement officials conducted an official meeting in Washington DC. They advised to set up a 'forensic science standards board' that will set specific standards for the methods used in Forensic Science and Crime labs. It means we also expect a mandatory proficiency testing for certified forensic odontologists in the near future which can prevent such kinds of wrongful convictions on the basis of dental evidence.

\section{CONCLUSION AND PRESENT STATUS OF DENTAL EVIDENCE}

The use of unique features and morphological variations of the teeth in personal identification is well accepted in forensic examinations and in the court of law [60]. In spite of advances in the leading identification techniques such as DNA profiling, fingerprints and facial reconstruction, the comparison of dental records (records in the form of dentist's observations and radiographs) play a significant role in the identification of the deceased in mass fatality incidents such as air plane crashes, other major accidents, terrorists' attacks and natural disasters. If the ante-mortem dental records are not available for comparison, then forensic anthropologist or odontologist can give clues regarding the age, race and sex of the deceased from the dental evidence recovered from the scene. However, in determination of age and sex from teeth one should be careful about population specificity as different population groups show varying degree of human variations in dental traits. This overview is an attempt to describe the significance of various kinds of dental evidence, techniques and methods used in forensic odontology for identification purposes.

As forensic odontologists are playing a major role in DVI and other medico-legal cases, there is an urgent need to promote this specialty. The initiatives such as sensitizing the dental science graduates towards this specialty and mandating the dentists with related casework experience and encouraging them to be a part of investigation and identification teams [61] can help to establish forensic odontology as a separate specialty under Forensic Sciences or Dental Sciences.

\section{CONFLICT OF INTEREST}

The authors confirm that this article content has no conflict of interest.

\section{ACKNOWLEDGEMENTS}

The authors are grateful to their respective Universities for encouraging publication of research in International Journals of Repute. 


\section{REFERENCES}

[1] Goldman AD. The scope of forensic dentistry, In: Cottone JA, Standish SM, Eds. Outline of Forensic Dentistry, Chicago: Yearbook Medical Publishers 1982; pp. 15-19.

[2] Krogman WM, Iscan MY. The human skeleton in forensic medicine, $2^{\text {nd }}$ ed. Springfield Illinois: Charles Thomas Publisher 1986; pp.189-243.

[3] Hinchliffe J. Forensic odontology, part 2. Major disasters. Br Dent J 2011; 210(6): 269-74.

[4] Hinchliffe J. Forensic odontology, Part 1. Dental identification. Br Dent J 2011; 210(5): 219-24.

[5] Pretty IA, Sweet D. A look at forensic dentistry--Part 1: The role of teeth in the determination of human identity. Br Dent J 2001; 190(7): 359-66.

[6] Williams LN. An introduction to forensic dentistry. Gen Dent 2013; 61(5): 16-7.

[7] Tinoco RL, Martins EC, Daruge E Jr, Daruge E, Prado FB, Caria PH. Dental anomalies and their value in human identification: a case report. J Forensic Odontostomatol 2010; 28(1): 39-43.

[8] Vij K. Text book of forensic medicine and toxicology-principles and practice; $5^{\text {th }}$ ed. New Delhi: Reed Elsevier India Private Limited-A Division of Elsevier 2011.

[9] Ambarkova V, Galić I, Vodanović M, Biočina-Lukenda D, Brkić H. Dental age estimation using Demirjian and Willems methods: Cross sectional study on children from the Former Yugoslav Republic of Macedonia. Forensic Sci Int 2014; 234: 187.e1-7.

[10] Olze A, Hertel J, Schulz R, Wierer T, Schmeling A. Radiographic evaluation of Gustafson's criteria for the purpose of forensic age diagnostics. Int J Legal 2012; 126(4): 615-21.

[11] Nuzzolese E, Di Vella G. Digital radiological research in forensic dental investigation: case studies. Minerva Stomatol 2012; 61(4): 165-73.

[12] Willems G. A review of the most commonly used dental age estimation techniques. J Forensic Odontostomatol 2001; 19(1): 9-17.

[13] Demirjian A, Goldstein H, Tanner JM. A new system for dental age estimation. Hum Biol 1973; 45: 211-27.

[14] Gustafson G. Age determination on teeth. J Am Dent Assoc 1950; 41(1): 45-54.

[15] Johanson G. Age determination from teeth. Odontol Revy 1971; 22: $1-126$.

[16] Kvaal SI, Kolltveit KM, Thomsen IO, Solheim T. Age estimation of adults from dental radiographs. Forensic Sci Int 1995; 74(3): $175-85$.

[17] Zorba E, Spiliopoulou C, Moraitis K. Evaluation of the accuracy of different molar teeth measurements in assessing sex. Forensic Sci Med Pathol 2013; 9(1): 13-23

[18] Khamis MF, Taylor JA, Malik SN, Townsend GC. Odontometric sex variation in Malaysians with application to sex prediction. Forensic Sci Int 2014; 234: 183. e1-7.

[19] Bakkannavar SM, Monteiro FN, Arun M, Kumar PG. Mesiodistal width of canines: a tool for sex determination. Med Sci Law 2012; 52(1): 22-6.

[20] Acharya AB, Mainali S. Sex discrimination potential of buccolingual and mesiodistal tooth dimensions. J Forensic Sci 2008; 53(4): 790-2.

[21] Joseph AP, Harisha RK, Mohammad PKR, Kumar VRB. How reliable is sex differentiation from teeth measurements? Oral Maxillofac Pathol J 2013; 4(1): 289-92.

[22] Rao NS, Rao NN, Pai ML, Kotain MS. Mandibular canine index - a clue for establishing sex identity. Forensic Sci Int 1989; 42: 24954.

[23] Acharya AB, Mainali S. Are dental indexes useful in sex assessment? J Forensic Odontostomatol 2008; 26(2): 53-9.

[24] Singh J, Gupta KD, Sardana V, Balappanavar AY, Malhotra G. Sex determination using cheiloscopy and mandibular canine index as a tool in forensic dentistry. J Forensic Dent Sci 2012; 4(2): 70-4

[25] Iscan MY, Kedici SP. Sexual variation in bucco-lingual dimensions in Turkish dentition. Forensic Sci Int 2003; 137: 160-4

[26] Galdames IS, Henríquez IR, Cantin M. Sex chromatin in dental pulp. Performance of diagnosis test and gold standard generation. Int J Morphol 2010; 28(4): 1093-6.
[27] Galdames IS, Flores A, Roa I, Cantín M, Zavando D. Sex determination by observation of barr body in teeth subjected to high temperatures. Int J Morphol 2011; 29(1): 199-203.

[28] Barr ML, Bertram LF, Lindsay HA. The morphology of the nerve cell nucleus, according to sex. Anat Rec 1950; 107(3): 283-97.

[29] Zapico SC, Ubelaker DH. Sex determination from dentin and pulp in a medicolegal context. J Am Dent Assoc 2013; 144(12): 137985.

[30] Ohira H, Yamamuro Y, Kitagawa Y, Nakagawa K, Yamamoto I, Yamada Y. Effective appropriate use of dental remains and forensic DNA testing for personal identity confirmation. Leg Med (Tokyo) 2009; 11(1): S560-2.

[31] Porto IM, Laure HJ, Tykot RH, de Sousa FB, Rosa JC, Gerlach RF. Recovery and identification of mature enamel proteins in ancient teeth. Eur J Oral Sci 2011; 119(1): 83-7.

[32] Nakahori Y, Hamano K, Iwaya M, Nakagome Y. Sex identification by polymerase chain reaction using $\mathrm{X}-\mathrm{Y}$ homologous primer. Am J Med Genet 1991: 39(4): 472-3.

[33] Nakahori Y, Takenaka O, Nakagome Y. A human X-Y homologous region encodes amelogenin. Genomics 1991; 9: 264-9.

[34] Alvarez-Sandoval BA, Manzanilla LR, Montiel R. Sex determination in highly fragmented human DNA by high-resolution melting (HRM) analysis. PLoS One 2014; 9(8): e104629.

[35] Michael A, Brauner P. Erroneous dender identification by the amelogenin sex test. J Forensic Sci 2004; 49(2): 258-9.

[36] Yaacob H, Nambiar P, Naidu MD. Racial characteristics of human teeth with special emphasis on the Mongoloid dentition. Malays J Pathol 1996; 18(1): 1-7.

[37] Edgar HJ. Estimation of ancestry using dental morphological characteristics. J Forensic Sci 2013; 58 (Suppl 1): S3-8.

[38] Nirmala SV, Gaddam KR, Vimaladevi P, Nuvvula S. Protostylid: A case series. Contemp Clin Dent 2013; 4(3): 349-52.

[39] Hemasathya BA, Balagopal S. A study of composite restorations as a tool in forensic identification. J Forensic Dent Sci 2013; 5(1): 35

[40] McClanahan JGH. Forensic Dentistry: Dental Indicators for Identification. Master's thesis, Department of Geography and Anthropology, University of Memphis 2003

[41] Ryan EJ. Identification through dental records. J Crim Law Criminol 1937; 28(2): 253-60.

[42] Jokstad A, Von Der Fehr FR, Løvlie GR, Myran T. Wear of teeth due to occupational exposure to airborne olivine dust. Acta Odontol Scand 2005; 63(5): 294-9.

[43] Pittayapat P, Jacobs R, De Valck E, Vandermeulen D, Willems G. Forensic odontology in the disaster victim identification process. Forensic Odontostomatol 2012; 30(1): 1-12

[44] Pinchi V, Norelli GA, Caputi F, Fassina G, Pradella F, Vincenti C. Dental identification by comparison of antemortem and postmortem dental radiographs: influence of operator qualifications and cognitive bias. Forensic Sci Int 2012; 222(1-3): 252-5.

[45] Hanihara T. Morphological variation of major human populations based on nonmetric dental traits. Am J Phys Anthropol 2008; 136(2): 169-82.

[46] Kanchan T, Machado M, Rao A, Krishan K, Garg AK. Enamel hypoplasia and its role in identification of individuals: A review of literature. Indian J Dent 2015; 6(2): 99-102.

[47] Nath S. Introduction to Forensic Anthropology. New Delhi: Gian Publishing House 1987.

[48] Barsley R, Freeman A, Metcalf R, Senn D, Wright F. Bitemark analysis. J Am Dent Assoc 2012; 143(5): 444

[49] Rothwell BR. Bite marks in forensic dentistry: a review of legal, scientific issues. J Am Dent Assoc 1995; 126(2): 223-32.

[50] Sweet D, Pretty IA. A look at forensic dentistry: Part 2: teeth as weapons of violence--identification of bite mark perpetrators. $\mathrm{Br}$ Dent J 2001; 28; 190(8): 415-8.

[51] Kaur S, Krishan K, Chatterjee PM, Kanchan T. Analysis and identification of bite marks in forensic casework. Oral Health Dent Manag 2013; 12(3): 127-31.

[52] Shukla D, Chowdhry A, Bablani D, Jain P, Thapar R. Establishing the reliability of palatal rugae pattern in individual identification (following orthodontic treatment). J Forensic Odontostomatol 2011; 29(1): 20-9. 
[53] Mustafa AG, Allouh MZ, Alshehab RM. Morphological changes in palatal rugae patterns following orthodontic treatment. J Forensic Leg Med 2015; 31: 19-22.

[54] Rath R, Reginald BA. Palatal rugae: An effective marker in population differentiation. J Forensic Dent Sci 2014; 6(1): 46-50.

[55] Dawasaz AA, Dinkar AD. Rugoscopy: predominant pattern, uniqueness, and stability assessment in the Indian Goan population. J Forensic Sci 2013; 58(6): 1621-7.

[56] Nagalaxmi V, Ugrappa S, Naga JM, Lalitha C, Maloth KN, Kodangal S. Cheiloscopy, palatoscopy and odontometrics in sex prediction and dis-crimination: a comparative study. Open Dent J 2015; 8: 269-9.
[57] The Wrongful Convictions Blog- Addressing wrongful conviction and actual innocence issues in an international forum, Available at: http://wrongfulconvictionsblog.org/2012/09/04 (Accessed on: 22 ${ }^{\text {nd }}$ March 2014).

[58] The Innocence Project, Available at: http://www. innocenceproject.org/ (Accessed on: 22 ${ }^{\text {nd }}$ March 2014).

[59] Reardon S. Faulty forensic science under fire. Nature 2014; 506(7486): 13-4.

[60] Riaud X. The first identification of forensic odontology endorsed by the American justice system. Dent Hist 2013; (58): 32-6.

[61] Kumar S, Dagli N. Forensic odontology: An area unexploredEditorial. J Int Oral Health 2014; 6(1): p.i.

Received: December 30, 2014

(C) Krishan et al.; Licensee Bentham Open.

This is an open access article licensed under the terms of the Creative Commons Attribution Non-Commercial License (http://creativecommons.org/licenses/by-nc/3.0/) which permits unrestricted, non-commercial use, distribution and reproduction in any medium, provided the work is properly cited. 